\title{
COMPOSITION AND CONCENTRATION OF PHENOLIC COMPOUNDS OF 'AUKSIS' APPLE GROWN ON VARIOUS ROOTSTOCKS
}

\author{
Darius Kviklys ${ }^{1, \#}$, Mindaugas Liaudanskas ${ }^{2}$, Jonas Viškelis ${ }^{1}$, Loreta Buskiené ${ }^{1}$, \\ Juozas Lanauskas ${ }^{1}$, Nobertas Uselis ${ }^{1}$, and Valdimaras Janulis ${ }^{2}$ \\ ${ }^{1}$ Institute of Horticulture, Lithuanian Research Centre for Agriculture and Forestry, Kauno 30, LT-54333, Babtai, \\ Kaunas distr., LITHUANIA \\ ${ }^{2}$ Department of Pharmacognosy, Lithuanian University of Health Sciences, A. Mickeviciaus 9, LT-44307 Kaunas, LITHUANIA \\ \# Corresponding author, dkviklys@gmail.com
}

Communucated by Dalija Seglina

\begin{abstract}
The trial was carried out at the Institute of Horticulture, Lithuanian Research Centre for Agriculture and Forestry in 2013-2015. CV. 'Auksis' was tested on 12 rootstocks: B.396, B.9, M.9, M.26, $P$ 22, P 59, P 61, P 62, P 66, P 67, PB.4, and Pure 1. Accumulation of phenolic compounds depended on fruit yield and average fruit weight. On average, significantly lower concentration among rootstocks occurred when apple trees had abundant yield and fruits were smaller. On average chlorogenic acid constituted $50 \%$ and total procyanidins $28 \%$ of total phenols in 'Auksis' fruits. Flavonoid concentration most depended on rootstock and the highest variation was recorded. More than 50\% difference occurred between the highest total flavonoid concentration in apples on PB.4 and the lowest on M.9 rootstocks. Low variability of total procyanidin concentration among rootstocks was observed. Differences between the highest and lowest concentration was $15 \%$. Total concentration of phenolic compounds differed among rootstocks by $29-35 \%$ depending on the year. Differences in accumulation of phenolic compounds depended on rootstock genotype but not on yield or fruit weight. PB.4 and P 67 rootstocks had the highest, and M.9, P 62 and M.26 had the lowest concentration of total phenol in 'Auksis' fruits.
\end{abstract}

Key words: bioactive substances, fruit, Malus $\mathrm{x}$ domestica Borkh., yield.

\section{INTRODUCTION}

Apples along with bananas are the most important fruits in the world. Apples also are distinguished by the highest amounts of phenolic compounds among fruits (Sun et al., 2002). Different apple cultivars as a source of variation of phytochemical content have been widely tested (Wolf et al., 2003; Ceymann et al., 2012; Liaudanskas et al., 2015; Wang et al., 2015; Xu et al., 2016).

Accumulation of phenolic compounds in apple fruits depends on climatic and technological factors: weather conditions (Scalzo et al., 2005), sun exposure (Awad et al., 2001), fruit position on the tree (Hagen et al., 2007; Feng et al., 2014) and fertilisation practice (Awad and de Jager, 2002). In spite of numerous studies of apple phenolic compounds, effect of rootstock on the accumulation of bioactive substances in apple fruits has not been widely tested. Rootstock choice is one of the most important decision in modern apple growing. Rootstock has obvious influence on apple tree development, precocity, and fruit quality, and it regulates transport of minerals in the tree. Studies on rootstocks of other orchard plants revealed great differences between rootstocks in accumulation of phenols, for example in lemon (Gil-Izquierdo et al., 2004) and cherry (Bauer et al., 1989), but studies of apple rootstock regarding phenolic compound concentration in fruits have been conducted only in Estonia and Lithuania (Mainla et al., 2011; Kviklys et al., 2014).

The aim of the study was to evaluate apple rootstock effect on accumulation of phenolic compounds in 'Auksis' fruits and to test impact of the rootstock on the variability and stability of bioactive substance concentration.

\section{MATERIALS AND METHODS}

The trial was conducted in a productive orchard at the Institute of Horticulture, Lithuanian Research Centre for Agriculture and Forestry in 2013-2015. Trees were planted at spacing $4 \times 1.5 \mathrm{~m}$ in 2005 and trained as slender spindle. 
Pest and disease management was carried out in conformity with the rules of integrated plant protection. Rootstocks for this trial were chosen based on their popularity worldwide and suitability for intensive apple growing: super-dwarf rootstocks P 22, P 59, P 61, and PB.4 (Belarusian selection), dwarf rootstocks M.9, P 62, P 66, P 67, B.396, B.9, and Pure 1 (Latvian selection), and semi-dwarf rootstock M.26 (Kviklys et al., 2013).

Rootstocks were grafted with cv. 'Auksis' and planted in a randomised block design, with four replicates and three trees per plot. Twenty randomly selected fruits from each replication were taken for biochemical analysis and carefully mixed. Twenty-five randomly selected fruits were chosen from the bulk sample and analysed in three replicates of composite samples.

Preparation of samples. Each apple was cut into slices of equal size (up to $1 \mathrm{~cm}$ in thickness), and the stalks and the seeds were removed. Slices were immediately frozen in a freezer $\left(-35^{\circ} \mathrm{C}\right)$ with air circulation and then lyophilised with a ZIRBUS sublimator $3 \times 4 \times 5 / 20$ (ZIRBUS technology, Bad Grund, Germany) at a pressure of 0.01 mbar (condenser temperature, $-85{ }^{\circ} \mathrm{C}$ ). The lyophilised apple slices were ground to a fine powder using a Retsch 200 mill (Haan, Germany). Loss on drying before analysis was determined by drying the apple lyophilisate in a laboratory drying oven to complete evaporation of water and volatile compounds (temperature, $105^{\circ} \mathrm{C}$; difference in weight between measurements up to $0.01 \mathrm{~g}$ ) and by calculating the difference in raw material weight before and after drying. Data were recalculated for absolute dry lyophilisate weight.

Chemicals. All the solvents, reagents, and standards used were of analytical grade. Acetonitrile and acetic acid were obtained from Sigma-Aldrich GmbH (Buchs, Switzerland) and ethanol from Stumbras AB (Kaunas, Lithuania). Hyperoside, rutin, quercitrin, phloridzin, procyanidin B1, procyanidin B2, and chlorogenic acid standards were purchased from Extrasynthese (Genay, France), (+)-catechin and (-)-epicatechin from Fluka (Buchs, Switzerland), and avicularin and isoquercitrin from Chromadex (Santa Ana, USA). Deionised water, produced by the Crystal E HPLC (Adrona SIA, Riga, Latvia) water purification system, was used.

Extraction. An amount of $2.5 \mathrm{~g}$ of lyophilised apple powder (exact weight) was weighed, added to $30 \mathrm{~mL}$ of ethanol $(70 \%, v / v)$, and extracted in a Sonorex Digital 10 P ultrasonic bath (Bandelin Electronic $\mathrm{GmbH} \& \mathrm{Co}$. KG, Berlin, Germany) for 20 minutes at $40{ }^{\circ} \mathrm{C}$. The conditions of extraction (type of extraction, duration, temperature, solvent and its concentration) were chosen considering the results of extraction optimisation. The obtained extract was filtered through a paper filter; the apple lyophilisate on the filter was washed twice with $10 \mathrm{~mL}$ of ethanol $(70 \%, \mathrm{v} / \mathrm{v})$ in a $50-\mathrm{mL}$ flask. The extract was filtered through a membrane filter with a pore size of $0.22 \mu \mathrm{m}$ (Carl Roth $\mathrm{GmbH}$, Karlsruhe, Germany).
Instrumentation and chromatographic conditions. Hyperoside, isoquercitrin, rutin, avicularin, quercitrin, (+)-catechin, (-)-epicatechin, procyanidin $\mathrm{B} 1$, procyanidin $\mathrm{B} 2$, phloridzin, and chlorogenic acid standards were dissolved in ethanol $(96.3 \%, \mathrm{v} / \mathrm{v})$. A mixture of these standards, diluted with ethanol $(96.3 \%, \mathrm{v} / \mathrm{v})$ to $1 / 2,1 / 4,1 / 8$, and $1 / 16$ of the initial concentration, was prepared. The initial mixture of standards and the diluted solutions were injected into the HPLC system. A calibration curve with five concentration levels was constructed for each compound. The analyses of standard solutions were performed in triplicate. The concentrations of phenolic compounds identified in the apple extracts were within the limits of calibration curves.

A Waters 2695 chromatograph equipped with a Waters 2998 photodiode array (PDA) detector (Waters, Milford, USA) was used for HPLC analysis. Chromatographic separation was managed, chromatograms were recorded, and data were processed with the Empower ${ }^{\circledR}$ v.2.0. software (Waters, Milford, USA). Chromatographic separations were carried out by using a YMC-Pack ODS-A $\left(5 \mu \mathrm{m}, \mathrm{C}_{18}, 250 \times\right.$ $4.6 \mathrm{~mm}$ i.d.) column equipped with a YMC-Triart $(3 \mu \mathrm{m}$, $\mathrm{C}_{18}, 10 \times 3.0 \mathrm{~mm}$ i.d.) precolumn (YMC Europe $\mathrm{GmbH}$, Dinslaken, Germany). The column was operated at a constant temperature of $25{ }^{\circ} \mathrm{C}$. The volume of the extract being investigated was $10 \mu \mathrm{L}$. The flow rate was $1 \mathrm{~mL} / \mathrm{min}$, and gradient elution was used. The mobile phase consisted of $2 \%(\mathrm{v} / \mathrm{v})$ acetic acid in water (solvent A) and 100\% (v/v) acetonitrile (solvent $\mathrm{B}$ ). The following conditions of elution were applied: 0-30 minutes, 3-15\% B; 30-45 minutes, 15-25\% B; 45-50 minutes, 25-50\% B; and 50-55 minutes, $50-95 \%$ B. Detection was simultaneously performed at three wavelengths: $280 \mathrm{~nm}$ (dihydrochalcones, catechins, procyanidins), $320 \mathrm{~nm}$ (phenolic acids), and $360 \mathrm{~nm}$ (flavonols). The spectrum of UV-visible light was recorded from 200 to $600 \mathrm{~nm}$. All the phenolic compounds were identified by comparing their retention times and spectra with those of the standard compounds. The concentration of phenolic compounds was calculated based on the peak areas by using standard compounds (Fig. 1).

The data on the main traits were subjected to the analysis of variance. Significance of differences between treatment (rootstock) means was evaluated using the LSD test at $p<$ 0.05 .

\section{RESULTS}

The total phenol concentration in 'Auksis' apples varied between rootstocks and years (Fig. 2). Differences between rootstocks were not the same during years of the study. In 2013, the lowest concentration of total phenolic compounds was recorded on P 62 rootstock (3741 $\mu \mathrm{g} / \mathrm{g}$ DW) and the highest - on P 59 rootstock $(5745 \mu \mathrm{g} / \mathrm{g} \mathrm{DW})$. In 2014, the lowest concentration was on M.9 (3147 $\mu \mathrm{g} / \mathrm{g}$ DW) and the

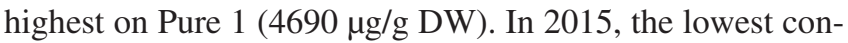
centration was recorded again on M.9 (3891 $\mu \mathrm{g} / \mathrm{g}$ DW) and the highest on P $62(5475 \mu \mathrm{g} / \mathrm{g}$ DW $)$. 


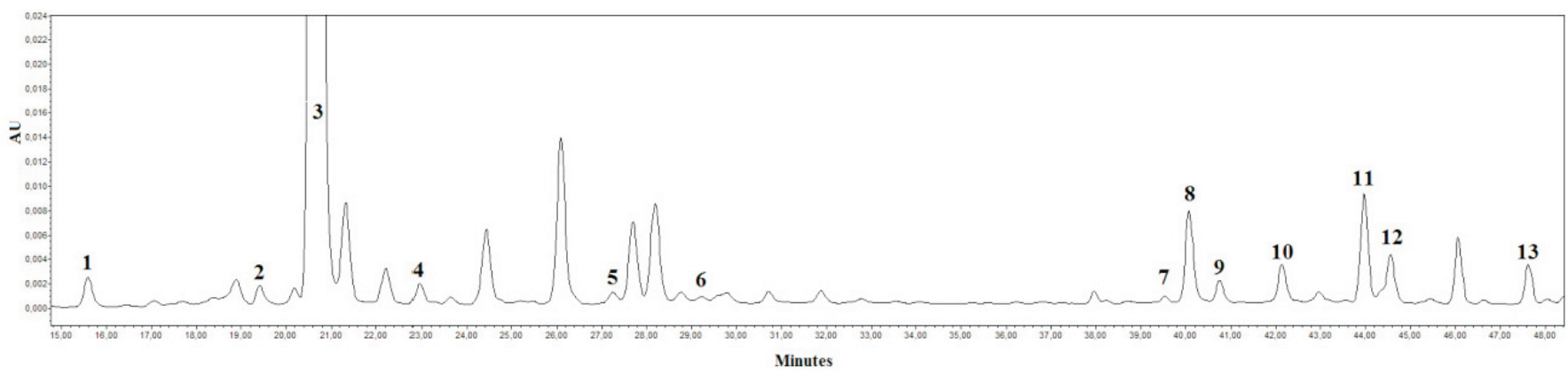

Fig. 1. Chromatogram of the ethanol extract of cv. 'Auksis' on M.9 rootstock fruit sample $(\lambda=320 \mathrm{~nm})$. Numbers indicate the peaks of analytes: $(1)$ procyanidin B1; (2) (+)-catechin; (3) chlorogenic acid; (4) procyanidin B2; (5) (-)-epicatechin; (6) procyanidin C1; (7) rutin; (8) hyperoside; (9) isoquercitrin; (10) reinotrin; (11) avicularin; (12) quercitrin; (13) phloridzin.

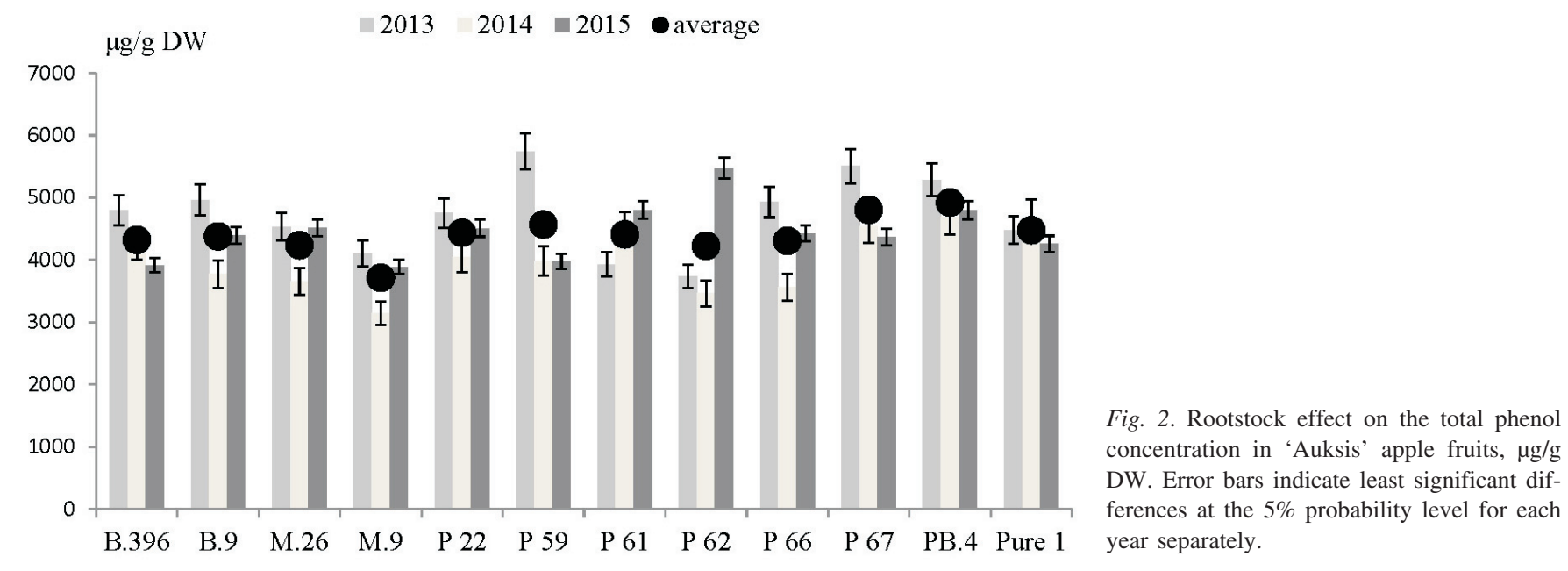

On average over three years, PB.4 and P 67 rootstocks accumulated the highest (4924 and $4804 \mu \mathrm{g} / \mathrm{g}$ DW respectively), while M.9 rootstock accumulated the lowest concentration of total phenols $(3714 \mu \mathrm{g} / \mathrm{g} \mathrm{DW})$.

Significant differences between rootstocks were observed in concentration of different phenolic compounds (Table 1). The highest concentration of quercetin glycosides (hypero- side, isoquercitrin, rutin, avicularin, and quercitrin) was found in fruits from trees grown on super dwarf rootstocks PB.4, P 59, and Pure 1. In contrast, the most vigorous trees on M.26 rootstock accumulated the lowest concentration of quercetin glycosides. M.9 rootstock significantly differed from other rootstocks in low accumulation of epicatechin, procyanidins, phloridzin, and chlorogenic acid. 'Auksis' ap-

Table 1

ROOTSTOCK EFFECT ON THE AVERAGE CONCENTRATION OF PHENOLIC COMPOUNDS IN 'AUKSIS' APPLE FRUITS, $\mu \mathrm{g} / \mathrm{g}$ DW, AVERAGE OF 2013-2015.

\begin{tabular}{|c|c|c|c|c|c|c|c|c|c|c|c|}
\hline Rootstock & Hyperoside & Isoquercitrin & Rutin & Avicularin & Quercitrin & Catechin & Epicatechin & ProcyanidinB 1 & ProcyanidinB2 & Phloridzin & $\begin{array}{c}\text { Chlorogenic } \\
\text { acid }\end{array}$ \\
\hline B.396 & 87.7 & 16.5 & 14.6 & 74.6 & 57.9 & 165 & 373 & 209 & 1099 & 123 & 2103 \\
\hline B.9 & 108.6 & 20.3 & 15.6 & 89.8 & 68.1 & 158 & 359 & 200 & 1006 & 112 & 2241 \\
\hline M.26 & 47.7 & 11.5 & 11.8 & 50.1 & 44.1 & 174 & 377 & 228 & 1031 & 149 & 2112 \\
\hline M.9 & 59.9 & 14.1 & 12.6 & 56.0 & 45.5 & 149 & 326 & 140 & 924 & 98 & 1890 \\
\hline P 22 & 77.9 & 16.6 & 15.2 & 70.4 & 56.1 & 174 & 399 & 223 & 1021 & 107 & 2276 \\
\hline P 59 & 121.8 & 25.6 & 22.0 & 105.9 & 78.4 & 164 & 359 & 218 & 1040 & 116 & 2320 \\
\hline P 61 & 91.8 & 18.4 & 15.3 & 79.8 & 64.5 & 153 & 403 & 197 & 1085 & 115 & 2188 \\
\hline P 62 & 74.6 & 16.0 & 13.4 & 70.8 & 57.5 & 167 & 391 & 179 & 1013 & 120 & 2123 \\
\hline P 66 & 79.2 & 16.8 & 13.7 & 72.6 & 59.2 & 127 & 379 & 230 & 1026 & 133 & 2171 \\
\hline P 67 & 81.6 & 17.5 & 14.5 & 74.4 & 58.6 & 182 & 434 & 235 & 1162 & 146 & 2398 \\
\hline PB.4 & 129.2 & 25.9 & 19.0 & 103.2 & 78.5 & 140 & 429 & 239 & 1082 & 116 & 2562 \\
\hline Pure 1 & 127.2 & 25.6 & 17.9 & 102.1 & 79.0 & 168 & 391 & 170 & 1052 & 153 & 2191 \\
\hline Mean & 90.6 & 18.7 & 15.5 & 79.1 & 62.3 & 160 & 385 & 206 & 1045 & 124 & 2215 \\
\hline $\mathrm{LSD}_{05}$ & 14.6 & 5.1 & 4.3 & 12.2 & 9.9 & 14.9 & 39.3 & 18.6 & 81.5 & 10.7 & 140.6 \\
\hline
\end{tabular}


VARIATION OF PHENOLIC COMPOUND CONCENTRATION IN 'AUKSIS' APPLE FRUITS DURING THREE GROWING SEASONS ON DIFFERENT ROOTSTOCKS, AVERAGE OF 2013-2015, VARIATION COEFFICIENT V\%.

\begin{tabular}{|c|c|c|c|c|c|c|c|c|c|c|c|c|}
\hline Rootstock & Hyperoside & Isoquercitrin & Rutin & Avicularin & Quercitrin & Catechin & Epicatechin & ProcyanidinB1 & ProcyanidinB2 & Phloridzin & $\begin{array}{c}\text { Chlorogenic } \\
\text { acid }\end{array}$ & $\begin{array}{c}\text { Total } \\
\text { phenol } \\
\text { content }\end{array}$ \\
\hline B.396 & 36 & 35 & 14 & 27 & 16 & 4 & 3 & 41 & 31 & 14 & 5 & 13 \\
\hline B.9 & 13 & 6 & 26 & 17 & 17 & 11 & 9 & 38 & 26 & 23 & 15 & 14 \\
\hline M.26 & 43 & 31 & 35 & 33 & 29 & 4 & 15 & 53 & 28 & 65 & 12 & 12 \\
\hline M.9 & 53 & 48 & 25 & 38 & 25 & 2 & 14 & 22 & 34 & 26 & 12 & 14 \\
\hline P 59 & 34 & 34 & 42 & 21 & 12 & 16 & 16 & 65 & 38 & 10 & 21 & 22 \\
\hline P 61 & 45 & 22 & 43 & 37 & 27 & 13 & 20 & 39 & 10 & 37 & 16 & 10 \\
\hline P 62 & 30 & 13 & 27 & 25 & 22 & 26 & 32 & 40 & 38 & 35 & 24 & 26 \\
\hline P 66 & 47 & 29 & 19 & 39 & 19 & 43 & 6 & 57 & 30 & 34 & 13 & 16 \\
\hline P 67 & 56 & 41 & 27 & 47 & 30 & 17 & 3 & 46 & 19 & 31 & 13 & 13 \\
\hline PB. 4 & 12 & 21 & 2 & 22 & 28 & 40 & 5 & 44 & 13 & 12 & 13 & 6 \\
\hline Mean & 35 & 26 & 26 & 30 & 22 & 18 & 11 & 42 & 25 & 29 & 13 & 13 \\
\hline
\end{tabular}

ples grown on P 67 and PB.4 rootstocks had the richest concentration of the latter phenolic compounds.

During the trial period the most stable concentration (coefficient of variation $(\mathrm{V} \%)=5$ and 6$)$ of total phenolic compounds was found in trees on PB. 4 and Pure 1 rootstocks (Table 2). The most variable concentration of total phenolic compounds in three years of investigations was recorded in apples on P 62 and P 59 rootstocks (V\% = 26 and 22, respectively). On average for the rootstocks, procyanidin B2 and hyperoside concentrations were the most variable, while epicatechin and chlorogenic acid concentrations were the most stable ( $\mathrm{V} \%=11$ and 13, respectively). Variation of separate phenolic compound concentration depended on rootstock. Very high variation $(\mathrm{V} \%>50)$ of hyperoside was recorded in 'Auksis' apples grown on M.26 and P 67 rootstocks, procyanidin B1 - on P 59 and phloridzin - on M.26 rootstock. The lowest variation (V\% 10) of isoquercitrin concentration during three years was recorded on B.9, rutin on PB.4, catechin on B.396, B.9, P 22, and M.26, epicatechin on B.396, B.9, P 22, P 66, P 67, PB.4, and Pure 1, procyanidin B1 on Pure 1, and chlorogenic acid on B.396 and $\mathrm{P} 22$ rootstocks.

The average apple yield was obtained in 2014 and fruits this year were distinguished by the lowest concentration of total phenols (Table 3). When the average yield was low, significantly higher concentration of phenols accumulated. Such relationships were not found for average fruit weight.

On average for the rootstocks, tree growth was negatively correlated $(\mathrm{r}=-0.55)$ with phenol concentration in fruits (Fig. 3).

On average for three years, fruit colour was positively correlated with the total phenol concentration $(r=0.62)$ (Fig. 4), although fruits from P 67 rootstock had only intermediate blush. However, by separate years, strong correlation
Table 3

AVERAGE ANNUAL APPLE YIELD, FRUIT WEIGHT AND TOTAL CONCENTRATION OF PHENOLIC COMPOUNDS IN 'AUKSIS' APPLES, AVERAGE OF 12 ROOTSTOCKS

\begin{tabular}{lccccc}
\hline & 2013 & 2014 & 2015 & $\mathrm{LSD}_{05}$ \\
\hline Total phenols, $\mu \mathrm{g} / \mathrm{g}$ DW & 4731 & 4025 & 4445 & 298 \\
Yield, kg/tree & 5.4 & 29.6 & 9.8 & 4.6 \\
Fruit weight, g & 157 & 138 & 183 & 24
\end{tabular}

between fruit colour and the total concentration of phenolic compounds was established only in 2013 ( $\mathrm{r}=0.69$ ), medium in $2014(\mathrm{r}=0.42)$ and no correlation in $2015(\mathrm{r}=$ 0.09) (data not presented).

\section{DISCUSSION}

Cv. 'Auksis' is one of the most popular apple cultivars grown in commercial and amateur orchards in Baltic countries (Univer et al., 2010; Lepsis et al., 2014). Along with good yield and excellent fruit quality, cv. 'Auksis' accumulates the highest concentration of phenolic compounds in comparison with some other commercially important apples cultivars grown in Lithuania (Liaudanskas et al., 2015). Our study demonstrated that total phenol concentration even could be increased by selecting the proper rootstock genotype, thereby enhancing the value of 'Auksis' fruits.

Cv. 'Auksis', like many apple cultivars, has biennial fruiting habit (Kviklys et al., 2016). Average apple yield during the investigation period differed significantly and it was inherent for all rootstocks tested. Average total phenol concentration was significantly lower in high yielding years and higher when apple had less abundant yield. Despite this overall phenomena, annual yield differences did not affect accumulation of phenols in fruits grown on B.396, P 61, 

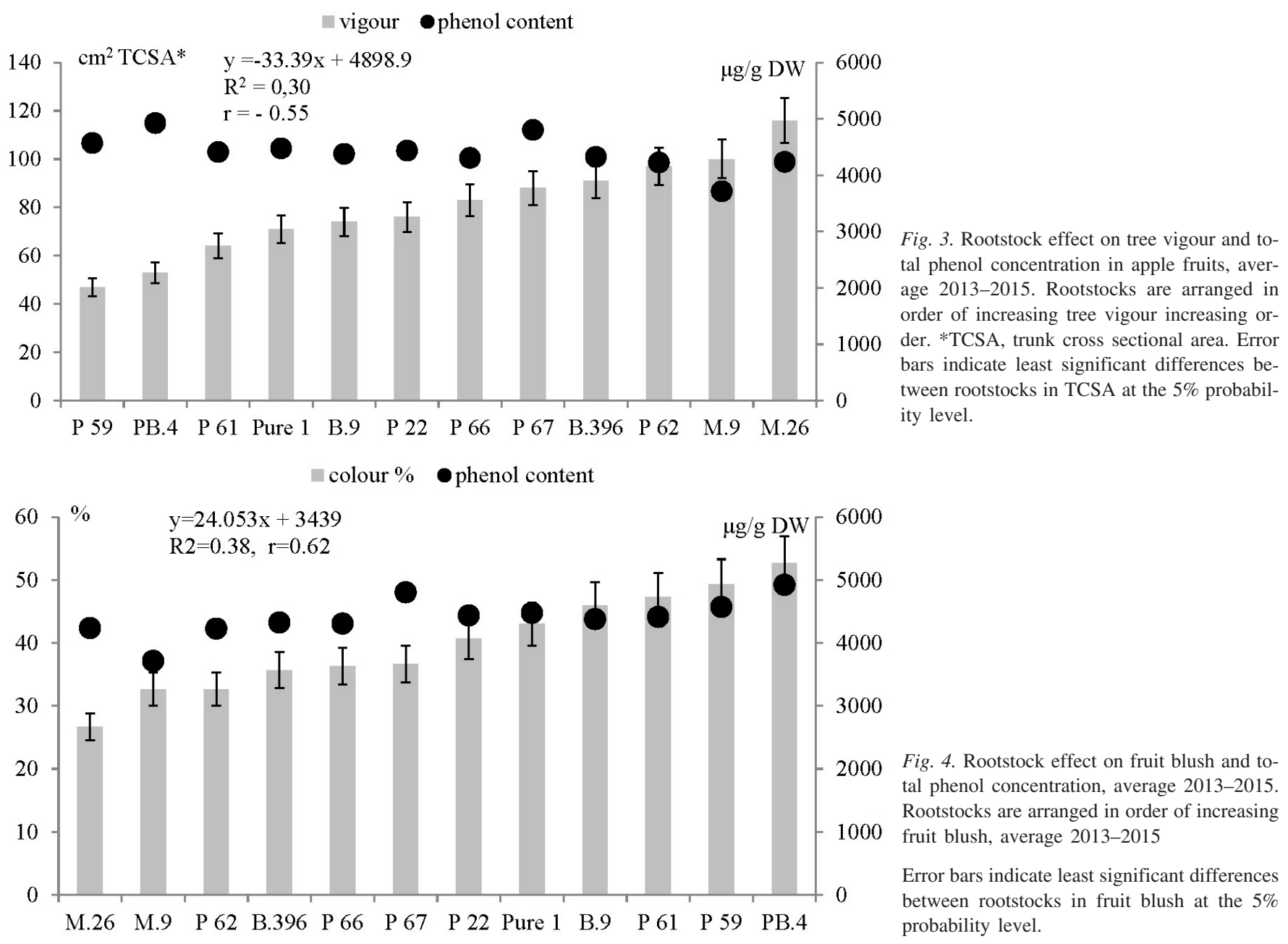

P 67, and Pure 1 rootstocks, indicating that the accumulation of phenols is more related to rootstock genotype.

Accumulation of phenolic compounds depends on climatic conditions. Differences of their concentration in apple fruits could be caused also by other factors (as yield, nutrition, soil management (Awad and de Jager, 2002; Wang and Lin, 2003; Mittelstras et al., 2006; Lanauskas et al., 2016). Depending on the year, the total concentration of phenolic compounds differed among rootstocks by $29-35 \%$. Choosing the right rootstock with stable phenol concentration could be achieved in the future. In our trials, rootstocks Pure 1 and PB.4 demonstrated very stable accumulation of total phenolic compounds despite variable yield and vegetation conditions. In order to achieve stability of individual phenolic compound concentration, certain rootstock cultivar combinations should be considered, as results from the trial with cultivar 'Ligol' demonstrated slightly different rootstock behaviour (Kviklys et al., 2014).

Flavonoids play an important role in tree growth processes and auxin transport (Buer et al., 2010). It has been established that more colourful fruits contain more quercetin glycosides. Lu et al. (1999) demonstrated significantly higher concentrations of quercetin glycosides in fully coloured fruits from the top of the tree and low concentrations in not coloured fruits from the inner canopy. Similar results were obtained by Hagen et al. (2007) and Feng et al. (2014). Our trial results confirm these findings. 'Auksis' apples from trees on M.26 rootstock were at least colourful and the content of quercetin glycosides in apples on this rootstock was the lowest. In contrast, significantly higher concentration of the main flavonoids were found in apples grown on PB.4 and P 59 rootstocks, which also positively influenced fruit colouration. More intensive fruit colour had effect on quercetin glycoside concentration but not on total phenolic compound concentration.

Mainla et al. (2011) reported that vigorous rootstocks accumulated less phenolic compounds in a trial performed in Estonia. However, there were only three rootstocks tested. Medium negative correlation established between tree growth and concentration of total phenolic compounds in our trial, but rootstock genotype played more important role in accumulation of phenolic compounds than induced tree vigour. The most vigorous rootstock M.26 had an intermediate concentration of phenolic compounds, while super dwarf PB.4 and dwarf P 67 had the highest concentration . The lowest accumulation of total phenols was detected in fruits grown on dwarf M.9 rootstock, the vigour of which did not differ significantly from P 67, which had the highest phenol concentration in 'Auksis' apples. Negative influence of M.9 rootstock on total phenol concentration was recorded also in a previous trial (Kviklys et al., 2014). 


\section{REFERENCES}

Awad, M., Wagenmakers, P., deJager, A. (2001). Effects of light on flavonoids and chlorogenic acid levels in the skin of 'Jonagold' apples. Sci. Hort., 88, 289-298.

Awad, M. A., de Jager, A. (2002). Relationships between fruit nutrients and concentrations of favonoids and chlorogenic acid in 'Elstar' apple skin. Sci. Hort., 92, 265-276.

Bauer, H., Treutter, D., Schmid, P. P. S., Schmitt, E., Feucht, W. (1989). Specific accumulation of o-diphenols in stressed leaves of Prunus avium. Phytochemistry, 28, 1363-1364.

Buer, C. S., Imin, N., Djordjevic, M. A. (2010). Flavonoids: New roles for old molecules. J. Integrative Plant Biol., 52 (1), 98-111

Ceymann, M., Arrigoni, E., Schärer ,H., Nising, A. B., Hurrell, R. (2012). Identification of apples rich in health-promoting flavan-3-ols and phenolic acids by measuring the polyphenol profile. J. Food Compos. Anal., 26,128-135.

Feng, F., Li, M., Ma, F., Cheng, L. (2014). Effects of location within the tree canopy on carbohydrates, organic acids, amino acids and phenolic compounds in the fruit peel and flesh from three apple (Malus $\times$ domestica) cultivars. Hort. Res., Article number: 14019 (2014). doi:10.1038/hortres.2014.19.

Gil-Izquierdo, A., Riquelme, M., Porras, I., Ferreres, F. (2004). Effect of the rootstock and interstock grafted in lemon tree (Citrus limon (L.) Burm.) on the flavonoid content of lemon juice. J. Agric. Food Chem., 52, 324-331.

Hagen, S. F., Borge, G. I. A., Bengtsson, G. B., Bilger, W., Berge, A., Haffner, K., Solhaug, K. A. (2007). Phenolic contents and other health and sensory related properties of apple fruit (Malus domestica Borkh., cv. Aroma): Effect of postharvest UV-B irradiation. Postharv. Biol. Technol., 45, $1-10$.

Ju, Z., Liu, C., Yuan, Y., Wang, Y., Liu, G. (1999). Coloration potential, anthocyanin accumulation, and enzyme activity in fruit of commercial apple cultivars and their F1 progeny. Sci. Hort., 79, 39-50.

Kviklys, D., Čeidaitė, A., Lanauskas, J., Uselis, N., Samuolienė G. (2016). The effect of rootstock on apple tree bearing stability in a cooler climate. Agric. Food Sci., 25 (1), 81-88.

Kviklys, D., Liaudanskas, M., Janulis, V., Viškelis, P., Rubinskienė, M., Lanauskas, J., Uselis, N. (2014). Rootstock genotype determines phenol content in apple fruits. Plant Soil Environ., 60 (5), 234-240.
Kviklys, D., Kviklienė, N., Bielicki, P., Bite, A., Lepsis, J., Univer, T., Univer, N., Uselis, N., Lanauskas J. (2013). Baltic fruit rootstock studies: Evaluation of apple (Malus domestica Borkh.) new rootstocks. Zemdirbyste-Agriculture, 100 (4), 441-446.

Lanauskas, J., Kviklys, D., Liaudanskas, M., Janulis, V., Uselis, N., Viškelis, J., Viškelis, P. (2017). Lower nitrogen nutrition determined higher phenolic content of organic apples. Hort. Sci. (Prague) (in press). Available at: http://www.agriculturejournals.cz/web/hortsci.htm?type=article\&id=50_2016-HORTSCI

Lepsis, J., Bite A., Kviklys D., Univer N. (2014). Evaluation of ‘Auksis' apple trees On dwarfing rootstocks in the Baltic Region. Acta Hort., 1058, 601-606.

Liaudanskas, M., Viškelis, P., Kviklys, D., Raudonis, R., Janulis, V. (2015). A comparative study of phenolic content in apple fruits. Int. J. Food Properties, 18 (5), 945-953.

Mainla, L., Moor, U., Karp, K., Püssa, T. (2011). The effect of genotype and rootstock on polyphenol composition of selected apple cultivars in Estonia. Žemdirbystè-Agriculture, 98 (1), 63-70.

Mittelstraß, K., Treutter, D., Pleß1, M., Heller, W., Elstner, E. F., Heiser, I. (2006). Modification of primary and secondary metabolism of potato plants by nitrogen application differentially affects resistance to Phytophthora infestans and Alternaria solani. Plant Biol., 8, 653-661.

Scalzo, J., Politi, A., Pellegrini, N., Mezzetti, B., Battino, M. (2005). Plant genotype affects total antioxidant capacity and phenolic contents in fruit. Nutrition, 21, 207-213.

Sun, J., Chu, Y., Wu, X., Liu, R. (2002). Antioxidant and antiproliferative activities of common fruits. J. Agric. Food Chem., 50, 7449-7454.

Univer, T., Kviklys, D., Lepsis, J., Univer, N. (2010). Early performance of "Auksis" apple trees on dwarfing rootstocks in Baltic region. Agron. Res., 8, 743-748.

Wang, X., Li, C., Liang, D., Zou, Y., Li, P., Ma, F. (2015). Phenolic compounds and antioxidant activity in red-fleshed apples. J. Funct. Foods, 18, 1086-1094.

Wang, S. Y., Lin, H. S. (2003). Compost as a soil supplement increases the level of antioxidant compounds and oxygen radical absorbance capacity in strawberries. J. Agric. Food Chem., 51, 6844-6850.

Wolfe, K, Wu, X, Liu, R. (2003). Antioxidant activity of apple peels. J. Agric. Food Chem., 51, 609-614.

Xu, Y., Fan, M., Ran, J., Zhang, T., Sun, H., Dong, M., Zhang, Z., Zheng, H. (2016). Variation in phenolic compounds and antioxidant activity in apple seeds of seven cultivars. Saudi J. Biol. Sci., 23, 379-388.

Received 26 September 2016

Accepted in the final form 23 May 2017

\section{ŠKIRNES 'AUKSIS' ĀBOLU SASTĀVS UN FENOLU SAVIENOJUMU SATURS, AUDZĒJOT UZ DAŽĀDIEM POTCELMIEM}

Pētījums veikts Lietuvas lauksaimniecības un mežsaimniecības pētījumu centra Dārzkopības institūtā 2013.-2015. gadā. Škirne 'Auksis' tika pārbaudīta uz 12 potcelmiem: B.396, B.9, M.9, M.26, P 22, P 59, P 61, P 62, P 66, P 67, PB.4 un Pure 1. Fenolu savienojumu uzkrāšanās bija atkarīga no ražas lieluma un vidējā augḷu svara. Vidēji uz visiem potcelmiem ievērojami zemāks fenolu saturs novērots tad, kad ābeles bagātīgi ražoja un aug̣̣i bija sīkāki. Vidēji šķirnes 'Auksis' augḷos hlorogēnskābe veidoja 50\% un kopējie procianidīni $28 \%$ no kopējā fenolu satura. Flavonoīdi bija visvairāk atkarīgi no potcelma, un tiem novērotas lielākās variācijas. Novērota vairāk nekā 50\% atškirīība starp augstāko kopējo flavonoīdu saturu augḷlos uz potcelma PB.4 un zemāko saturu uz M.9. Kopējiem procianidīniem atšḳirības atkarībā no potcelma bija mazas. Starpība starp augstāko un zemāko saturu bija 15\%. Kopējais fenolu savienojumu saturs atšķīrās starp potcelmiem par 29-35\% atkarībā no gada. Atškirības fenolu savienojumu uzkrāšanās daudzumā ietekmēja potcelma genotips, bet ne ražas lielums vai augḷu svars. Potcelmi PB.4 un P 67 deva augstāko, bet M.9, P 62 un M.26 zemāko kopējo fenolu saturu škirnes ‘Auksis’ auglos. 